\title{
Politik Hukum Perlindungan dan Pengelolaan Lingkungan Hidup
}

\author{
Sutrisno \\ Universitas Nahdlatul Ulama Surakarta/IAIN Surakarta \\ Jl. Ahmad Yani Pabelan Surakarta Jawa Tengah \\ trisno_061@yahoo.com
}

\begin{abstract}
To utilize natural resources for the good of the people as mandated by the Constitution 1945 and to retrieve prosperity based on the Five Principles of Pancasila, a sustainable environmen preservation corresponding to the national growth is highly needed. Al-Quran is rich ofverses teaching mankind the necessity for them to preserve the nature as God has appointed mankind as the caliph of the earth. This research is a library research aimed at obtaining a vivid description on the implementation of Environmental Preservation and Management Constitution. Deductive and comparative method were implemented to analyze the data. The analysis pointed out that the authority for environmental management control lingered in deviation as it did not conform to the aims of the political law. Law enforcement faces barriers due to the difficulty to determine exact criteria and measurements of environmental damage. Therefore, dedication and professionalism from the law enforcers and the societal environmental awareness of the people were required to execute the laws governing the utilization of environment.
\end{abstract}

Key words : Political law, protection, environmental management

\begin{abstract}
Abstrak
Dalam rangka mendayagunakan sumber daya alam untuk mewujudkan kesejahteraan umum seperti termuat dalam Undang-Undang Dasar 1945 dan untuk mencapai kebahagiaan hidup berdasarkan Pancasila, perlu diusahakan pelestarian lingkungan hidup yang serasi dan seimbang untuk menunjang pembangunan yang berkesinambungan. Kewajiban kita sebagai khalifah di bumi sudah selayaknya untuk menjaga dan melestarikan alam, banyak ayat-ayat Al-Qur'an yang menginformasikan ketidak pedulian manusia terhadap lingkungan hidup. Untuk memperoleh gambaran yang mendalam tentang implementasi Undang-Undang Perlindungan dan Pengelolaan Lingkungan Hidup, maka dalam penelitian ini metode pengumpulan data yang digunakan adalah penelitian pustaka (library research). Metode analisis data melalui metode deduksi dan metode komparasi. Hasil pembahasan menunjukkan bahwa wewenang pengendalian pengelolaan lingkungan hidup masih menyimpang belum berjalan pada arah tujuan politik hukumnya. Penegakan hukum sulit dilakukan karena sulitnya pembuktian dan menentukan kriteria baku tentang kerusakan lingkungan. Untuk itu perlu dedikasi dan profesionalisme aparat penegak hukum serta kesadaran masyarakat dalam melaksanakan ketentuan-ketentuan hukum lingkungan.
\end{abstract}

Kata kunci : Politik hukum, perlindungan, pengelolaan lingkungan 


\section{Pendahuluan}

Dalam rangka mendayagunakan sumber daya alam untuk memajukan kesejahteraan umum seperti termuat dalam Undang-Undang Dasar 1945 dan untuk mencapai kebahagiaan hidup berdasarkan Pancasila, perlu diusahakan pelestarian lingkungan hidup yang serasi dan seimbang untuk menunjang pembangunan yang berkesinambungan dilaksanakan dengan kebijaksanaan terpadu dan menyeluruh serta memperhitungkan kebutuhan generasi sekarang dan mendatang.

Untuk menjamin adanya kepastian hukum agar masyarakat mempunyai kesadaran untuk turut serta dalam melestarikan lingkungan mereka, pemerintah telah menyiapkan perangkat hukum khususnya hukum lingkungan untuk menjerat para pencemar dan perusak lingkungan hidup. Undang-Undang yang dimaksud adalah Undang-Undang Nomor 4 Tahun 1982 tentang Lingkungan Hidup (UULH) serta Undang-Undang Nomor 23 Tahun 1997 tentang Pengelolaan Lingkungan Hidup (UUPLH) dan telah disempurnakan dengan Undang-Undang yang terbaru yaitu Undang-Undang Nomor 32 Tahun 2009 tentang Perlindungan dan Pengelolaan Lingkungan Hidup (UUPPLH) yang sampai saat tulisan ini dibuat peraturan pelaksananya (PP) belum keluar. Keberadaan undang-undang ini diharapkan dapat menjadi bahan acuan bagi aparat penegak hukum untuk menindak fihak-fihak yang telah sengaja atau tidak sengaja telah melakukan pencemaran lingkungan. Para penegak hukum dapat menyelesaikan kasuskasus tindak pidana lingkungan yang terjadi, khususnya masalah pencemaran air oleh limbah industri yang sering marak terjadi terutama di kota-kota besar.

Praktek Good Environmental Governace dalam beberapa tahun ini di Indonesia menjadi sorotan publik. Kerusakan lingkungan dan menurunnya kualitas lingkungan seringkali dihubung-hubungkan bahkan sering dinyatakan bahwa penyebabnya adalah adanya Environmental Governace yang tidak sesuai dengan peraturan perundang-undangan yang semestinya. Kondisi ini sebagai akibat dari penyelengaraan corporate governance yang tidak memenuhi standar pengelolaan suatu institusi atau perusahaan. Penyimpangan ini ditandai dengan lemahnya penegakan hukum, pengadilan yang tidak mandiri, dan budaya KKN dalam aparatur birokrasi, dan kurang maksimalnya peran masyarakat. ${ }^{1}$ Dalam penjelasan umum Undang-Undang Perlindungan dan Pengelolaan Hidup dinyatakan bahwa lingkungan hidup yang baik dan sehat merupakan hak asasi

\footnotetext{
${ }^{1}$ Askin Mohammad, Hukum Lingkungan, Penerbit Yayasan Peduli Energi Indonesia (YPEI), Jakarta, 2008,
} hlm. 45 
dan hak konstitusional bagi setiap warga negara Indonesia. Oleh karena itu, negara, pemerintah, dan seluruh pemangku kepentingan berkewajiban untuk melakukan perlindungan dan pengelolaan lingkungan hidup dalam pelaksanaan pembangunan berkelanjutan agar lingkungan hidup Indonesia dapat tetap menjadi sumber dan menunjang hidup bagi rakyat Indonesia serta makhluk hidup lain. Negara Indonesia terletak pada posisi silang antara dua benua dan dua samudera dengan iklim tropis dan cuaca serta musim yang menghasilkan kondisi alam yang sangat tinggi nilainya. Indonesia mempunyai kekayaan keanekaragaman hayati dan sumber daya alam yang melimpah. Kekayaan itu perlu dilindungi dan dikelola dalam suatu sistem perlindungan dan pengelolaan lingkungan hidup yang terpadu dan terintegrasi antara lingkungan laut, darat, dan udara berdasarkan wawasan Nusantara. Selain itu pengelolaan lingkungan hidup harus dapat memberikan kemanfaatan ekonomi, sosial, dan budaya yang dilakukan berdasarkan prinsip kehati-hatian, demokrasi lingkungan, desentralisasi, serta pengakuan dan penghargaan terhadap kearifan lokal dan kearifan lingkungan. Perlindungan dan pengelolaan lingkungan hidup menuntut dikembangkannya suatu sistem yang terpadu berupa suatu kebijakan nasional yang harus dilaksanakan secara taat asas dan konsekuen dari pusat sampai daerah.

Kebutuhan akan tatanan hukum lingkungan yang fleksibel sangat dituntut seirama dengan perkembangan permasalahan yang muncul di lapangan. Organisasi swadaya masyarakat pemerhati lingkungan yang merupakan wakil dari masyarakat secara keseluruhan telah menuntut terciptanya lingkungan yang bersih dan sehat. Dan dibarengi kesadaran masyarakat terhadap permasalahan lingkungan hidup semakin tinggi. Maka konsep dasar hukum lingkungan harus diarahkan kepada kebijaksanaan dasar yang berwawasan lingkungan, untuk meningkatkan mutu hidup bebas dari pencemaran lingkungan.

Program pembinaan hukum lingkungan secara terpadu memang merupakan keharusan mengingat luasnya cakupan sektor pembangunan yang harus dikelola secara simultan. Hal ini menuntut kalangan hukum untuk melakukan pendekatan interdisipliner dan lintas sektoral. Beberapa sektor yang terkait dapat disebutkan diantaranya sektor kependudukan, kesehatan, transmigrasi, pemukiman dan perumahan, pertambangan, perindustrian, pertanian, kehutanan, kelautan, perdagangan, perikanan, pengairan, penataan ruang, dan sektor-sektor lain. ${ }^{2}$

${ }^{2}$ Ibid., hlm. 48. 
Penegakan hukum harus ditingkatkan, hukum harus mampu menjelaskan kriteria baku dari pada kerusakan lingkungan hidup. Karena kasus kerusakan lingkungan hidup oleh limbah industri/perusahaan lebih disebabkan oleh pemahaman terhadap batas kerusakan dan dampak yang ditimbulkan tidak diantisipasi oleh ketentuan atau undang-undang pengelolaan lingkungan hidup. Dengan undang-undang perlindungan dan pengelolaan lingkungan hidup yang telah disempurnakan ini diharapkan semua permasalahan lingkungan hidup dapat diselesaikan dengan baik dan tuntas, para pelaku dapat dikenakan pidana setimpal dengan perbuatannya.

Kewajiban kita semua sebagai khalifah di bumi sudah selayaknya untuk menjaga dan melestarikan alam, banyak ayat-ayat Al-Qur'an yang menginformasikan tentang ketidakpedulian manusia terhadap lingkungan hidup antara lain “Telah nampak kerusakan di darat dan di laut disebabkan perbuatan tangan manusia, supaya Allah merasakan pada mereka sebagai dari perbuatan mereka, agar mereka kembali (kejalan yang benar)”, , “Dan janganlah kamu merusak di muka bumi ini sesudah Allah membangunnya...", ", "Dan apabila dikatakan pada mereka : 'Janganlah kalian berbuat kerusakan di muka bumi' mereka menjawab : Sesungguhnya kami orang-orang yang mengadakan perbaikan", 4 "Dan diantara mereka ada orang yang ucapannya tentang kehidupan dunia menarik hatimu, dan diperselisihkannya kepada Allah (atas kebenaran) isi hati, padahal ia adalah penantang yang paling keras. Dan apabila ia berpaling (darimu) ia berjalan dibumi untuk untuk mengadakan kerusakan padanya, dia merusak tanam-tanaman dan binatang-binatang ternak, dan Allah tidak menyukai kebinasaan". ${ }^{5}$

\section{Rumusan Masalah}

Undang-Undang Nomor 32 Tahun 2009 diharapkan mampu menyelesaikan permasalahan lingkungan hidup, tetapi mengapa akhir-akhir ini masih banyak

\footnotetext{
${ }^{2}$ Qur'an Surat Ar Ruum Juz 21, Ayat 41, Qur'an Edisi Baru Revisi Terjemah 1993, Penerbit CV AL WAAH, Semarang, 1995, hlm. 647

${ }^{3}$ Qur'an Surat Al A'raaf Juz 8, Ayat 56, Qur'an Edisi Baru Revisi Terjemah 1993, Penerbit CV AL WAAH, Semarang, 1995, hlm. 230

${ }^{4}$ Qur'an Surat Al Baqoroh Juz 1, Ayat 11, Qur'an Edisi Baru Revisi Terjemah 1993, Penerbit CV AL WAAH, Semarang, 1995, hlm. 10

${ }^{5}$ Qur'an Surat Al Baqoroh Juz 2, Ayat 11, Qur'an Edisi Baru Revisi Terjemah 1993, Penerbit CV AL WAAH, Semarang, 1995, hlm. 204-205
} 
terjadi kerusakan lingkungan hidup. Dari uraian di atas dapat dirumuskan masalahnya, Pertama, apakah wewenang pengelolaan lingkungan hidup sudah berjalan sesuai tujuan politik hukumnya ? Kedua, bagaimana usaha penegakan hukum yang dilakukan oleh aparat penegak hukum?

\section{Tujuan Penelitian}

Berdasarkan permasalahan tersebut di atas, maka penulisan makalah ini bertujuan Pertama, untuk menjelaskan wewenang pengelolaan lingkungan hidup sudah berjalan sesuai tujuan politik hukumnya. Kedua, untuk menjelaskan penegakan hukum yang dilakukan oleh aparat penegak hukum.

\section{Metode Penelitian}

Dalam penulisan ini kami menggunakan beberapa metode antara lain Pertama, pengumpulan data, karena data yang dihimpun adalah data yang berasal dari kepustakaan, maka metode pengumpulan data yang digunakan adalah penelitian pustaka (library research), yakni dengan jalan mencari buku-buku dan karya tulisan yang berhubungan dengan lingkungan hidup. Adapun sumber rujukan dari tulisan ini dikaji dari berbagai buku dan karya ilmiah lainnya yang ada kaitannya dengan hukum lingkungan. Kedua, analisa data, 1. metode deduksi, yaitu suatu analisis data yang bertitik tolak atau berdasarkan pada kaidah-kaidah yang bersifat umum kemudian diambil suatu kesimpulan yang bersifat khusus. 2. metode komparasi, yaitu suatu sistem analisis data dengan cara membandingkan antara satu data dengan yang lain kemudian menarik kesimpulan untuk memperkuat salah satunya.

\section{Hasil dan Pembahasan}

\section{Wewenang Pengendalian/ Pengelolaan Lingkungan Hidup}

Lingkungan hidup yang baik dan sehat merupakan hak asasi setiap warga negara Indonesia sebagaimana diamaatkan dalam Pasal 28 H UUD 1945. Demikian juga untuk memajukan kesejahteraan umum sebagaimana yang tercantum dalam alinea ke-4 Pembukaan Undang-Undang Dasar 1945. Ketentuan ini menegaskan kewajiban negara dan tugas pemerintah untuk melindungi segenap sumber-sumber 
dalam lingkungan hidup Indonesia guna kebahagiaan seluruh rakyat Indonesia . Lebih konkrit pemikiran dasar tersebut diatur di dalam Pasal 33 ayat (3) sebagai berikut " Bumi dan air dan kekayaan alam yang terkandung di dalamnya dikuasai oleh Negara dan dipergunakan untuk sebesar-besarnya kemakmuran rakyat“. Ketentuan tersebut memberikan hak penguasaan kepada negara atas seluruh sumber daya alam Indonesia dan memberikan kewajiban kepada negara untuk menggunakannya bagi sebesar-besar kemakmuran rakyat. Dan juga untuk mencapai kebahagiaan hidup yang tertib, aman dan sejahtera berdasarkan landasan idiil Pancasila, maka perlu diusahakan pelestarian lingkungan hidup yang serasi dan seimbang untuk menunjang pembangunan yang berkesinambungan berdasarkan kebijakan nasional yang terpadu dan menyeluruh perlu di tetapkan sebuah undangundang sebagai landasan bagi pengelolaan lingkungan hidup.

Selama tiga dasawarsa terakhir ini, isu lingkungan dapat diidentifikasi menjadi dua kelompok besar, ${ }^{6}$ yaitu: masalah penurunan kualitas lingkungan berupa : penurunan kualitas dan kuantitas air, penurunan kualitan udara, kerusakan pesisir laut, penurunan kualitas lingkungan hidup perkotaan, kerusakan lingkungan fisik diantaranya penabangan hutan. Sedangkan yang kedua meliputi antara lain: keterbatasan dana, kelembagaan lingkungan hidup yang tidak memadai dan kapasitas sumber daya manusia yang sangat terbatas.

Penyelenggaraan pengelolaan lingkungan hidup dalam rangka pembangunan berkelanjutan yang berwawasan lingkungan hidup harus didasarkan kepada norma hukum dengan memperhatikan tingkat kesadaran masyarakat dan perkembangan lingkungan global serta perangkat hukum internasional yang berkaitan dengan lingkungan hidup.

Sejak diberlakukan Undang-Undang Lingkungan Hidup Nomor 4 Tahun 1982 sampai diberlakukannya undang-undang yang baru, implementasi undang-undang ini berjalan lambat. Banyak hal yang menyebabkan sehingga tidak berfungsi dengan baik secara konsep mengenai penyelesaian sengketa dalam pembuktian pelanggaran lingkungan kemudian secara operasional dalam upaya penegakan hukum. Oleh karena ketentuan tersebut disempurnakan dengan dikeluarkannya Undang-undang Nomor 32 Tahun 2009 tentang Perlindungan dan Pengelolaan Lingkungan Hidup. Kondisi pengelolaan lingkungan hidup sebelum berlakunya undang-undang ini

${ }^{6}$ Kem. Lingk. Hidup, Program Bangun Praja, Penerbit Yayasan Peduli Energy Indonesia, Jakarta, 2003, hlm. 10- 
masih belum tertata dengan baik atau masih carut marut. Bahkan pada awal terjadinya revolusi industri dengan dibangunnya perusahaan-perusahaan besar, saat asap mulai mengotori udara, limbah industri mulai mencemari air dan banyak banyak manusia yang tanpa disengaja ataupun disengaja mulai membuang sampahnya ke sungai, yang saat itu diprediksikan alam masih mampu membersihkan dirinya dengan daya adaptasinya sendiri. Manusia percaya dengan proses budaya dan pengetahuan tehnologi yang dimiliki mampu menyesuaikan diri atas perubahan perubahan pada lingkungan tempat dan keadaan saat itu. Bagaimana kalau alam sudah tidak mampu lagi membersihkan dirinya karena olah manusia yang tidak bertanggung jawab.

\section{Peraturan perundang-undangan di Bidang Lingkungan Hidup Jaman Kolonial dan Jaman Jepang}

Peraturan perundangan di bidang lingkungan hidup yang pertama kali diatur adalah mengenai Perikanan Mutiara dan Perikananan Bunga Karang (Stbl 1916 No 157). ${ }^{7}$ Menyusul kemudian dengan mendasarkan pada ketentuan Hinder Ordonantie (HO) sebagai hukum warisan kolonial/ penjajahan Belanda yang diadopsi berdasarkan Aturan Peralihan Pasal II Undang-Undang Dasar 1945 dimana ketentuan Hinder Ordonantie(HO) yang berorientasi pada larangan dengan tanpa ijin membuat kegiatan yang menimbulkan bahaya , kerusakan dan gangguan terhadap lingkungan yang diakibatkan adanya kegiatan dimana para pemrakarsa kegiatan diharuskan mendapatkan ijin kegiatan utamanya adanya persetujuan tetangga untuk melaksanakan kegiatan. Konsekuensinya adalah bahwa pemrakarsa tidak dapat melaksanakan kegiatannya, kalau dalam kegiatannya menimbulkan bahaya/gangguan dan pencemaran lingkungan, akan tetapi dalam kenyataannya masalah perijinan Hinder Ordonantie (HO) ini hanya dipakai sebagai prosedur saja oleh Pemeritah Daerah Kabupaten/Kota, karena ia tidak mempunyai struktur untuk menangani masalah lingkungan hidup sebagaimana diinginkan oleh politik hukum global yang berkembang saat ini. Prosedur Hinder Ordonantie (HO) ini tidak menyangkut mengenai masalah persetujuan lingkungan, ia hanya mengutamakan persetujuan tetangga. Proses lainnya yang bersinggungan dengan lingkungan masih tidak diatasi.

Pada jaman Jepang, hampir tidak ada peraturan perundangan-undangan di bidang lingkungan hidup yang dikeluarkan, kecuali Osamu S. Kanrei No. 6 yaitu

${ }^{7}$ Koesnadi Hardjasoemantri, Hukum Tata Lingkungan, Penerbit Gajah Mada University Press, Yogyakarta,2001, hlm. 57-59 
mengenai larangan menebang pohon aghata, alba dan balsem tanpa izin Gunseikan. Hal lain yang menarik perhatian mengenai kelestarian lingkungan di dalam Al Qur'an disebutkan beberapa surat yang menyatakan tentang upaya pelestarian lingkungan hidup. Di antaranya yaitu Surat Al Araaf ayat 56 “...dan janganlah kamu merusak di muka bumi sesudah Tuhan membangunnya..."

Hal ini merupakan kekuatan moral kepada pemeluknya agar senantiasa memelihara dan melestarikan lingkungan hidup. Ini bukan untuk mencampurkan antara ajaran agama dengan kekuatan hukum yang berlaku akan tetapi paling tidak dalam rangka pembentukan hukum lingkungan hidup yang baru, akan memberi dukungan moral yang sangat kuat dimana kita ketahui bahwa sebagaian besar penduduk bangsa Indonesia beragama Islam.

\section{Pembaharuan ke hukum nasional}

Tonggak sejarah politik hukum dari jaman kolonial ke jaman nasional dimulai tanggal 17 Agustus 1945 dengan adanya pernyataan Proklamasi oleh Bung Karno dan Bung Hatta. Semua aturan yang dibuat dalam rangka untuk menciptakan kemakmuran dan keadilan masyarakat harus bersumber kepada sumber dari segala sumber hukum yaitu Pancasila dan sumber tertib hukum yang tertinggi UndangUndang Dasar 1945. Kebijaksanaan pengelolaan lingkungan hidup di Indonesia adalah menyangkut pertanyaan "apa yang ingin dicapai, bagaimana dan jalan apa, dengan cara apa pengelolaan lingkungan dilaksanakan. ${ }^{8}$

Awal munculnya langkah dalam rangka penanganan masalah lingkungan hidup secara serius yang diilhami oleh Deklarasi tentang Lingkungan Hidup (Stockholm Declaration), hasil sidang/ konferensi PBB di Stockholm tanggal 5 s/d 16 Juni 1972, diikuti oleh 113 negara peserta dan puluhan peninjau.

Hasil konferensi berupa : a. deklarasi tentang lingkungan hidup manusia yang terdiri dari Preamble dan 26 azas yang lazim disebut dengan Stockholm Declaration. b. action plan lingkungan hidup. c. rekomendasi tentang kelembagaan dan keuangan yang menunjang pelaksanaan Action Plan tersebut. d. menetapkan tanggal 5 Juni sebagai Hari Lingkungan Hidup. ${ }^{9}$

\footnotetext{
${ }^{8}$ Siti Sundari Rangkuti, Hukum Lingkungan dan Kebijaksanaan Lingkungan, Penerbit Airlangga University Press, Malang, 2005, hlm. 7

${ }^{9}$ Koesnadi Hardjasoemantri, Op. Cit., hlm. 8-9
} 
Setelah Proklamasi Kemerdekaan Republik Indonesia dikeluarkan Keputusan Presiden Nomor 16 Tahun 1972, tentang Pembentukan Panitia Interdepartemental yang disebut : Panitia Perumus dan Rencana Kerja bagi Pemerintah di Bidang Pengembangan Lingkungan Hidup. Panitia ini berhasil merumuskan program pembangunan lingkungan hidup, kemudian dituangkan dalam Ketetapan MPR No. IV Tahun 1973, tentang Garis-Garis Besar Haluan Negara ( GBHN 1973 - 1978 ) dalam BAB III, bagian B ayat 10, yang kemudian dijabarkan lebih lanjut melalui Keputusan Presiden RI Nomor 11 Tahun 1974 tentang REPELITA II, bab 4 tentang pengelolaan sumber daya alam dan lingkungan hidup.

Panitia Perumus terus bekerja dan berupaya agar bisa mengembangkan diri serta mampu membuat konsep yang jelas dalam rangka penanganan masalah lingkungan. Adanya dorongan kuat pembenahan masalah lingkungan secara konsepsional di Indonesia adalah adanya kasus pencemaran lingkungan yang terjadi pada saat itu dan bisa dijadikan sandaran bagi panitia perumus untuk membuat konsep secara aktual. Yaitu adanya kasus pencemaran lingkungan laut akibat kecelakaan kapal tanker raksasa "Show Maru “ di perairan Karang "Buffalo Rocks" yang terletak kurang lebih $3 \mathrm{~km}$ dari pelabuhan Singapura yang menyebabkan masalah yang besar bagi pemerintah Singapura dan Indonesia dalam hal penyelesaian melalui hukum dan tuntutan ganti rugi. Hal ini di karenakan Indonesia belum mempunyai undang-undang penanggulangan kerusakan lingkungan hidup dan belum diratifikasikannya konvensi-konvensi International mengenai hal tersebut.

Dalam rangka pembinaan aparatur pengelolaan lingkungan hidup maka pada tahun 1978 telah diangkat untuk pertama kali dalam kabinet, yaitu dalam Kabinet Pembangunan III (1978-1983), seorang Menteri yang mengkoordinasikan aparatur pemerintah dalam pengelolaan sumber daya alam dan lingkungan hidup yaitu Menteri Negara Pengawasan Pembangunan dan Lingkungan Hidup (PPLH), sebagai menteri pertama yang menangani masalah lingkungan hidup adalah Prof. Dr. Emil Salim, yang menjabat sampai 3 kali periode. Baru pada Kabinet Pembangunan VI (1993-1998) telah diangkat Sarwono Kusumaatmadja sebagai Menteri Negara Lingkungan Hidup. Dalam Kabinet Pembangunan VII (1998 - 1998) telah diangkat Yuwono Sudarsono Sebagai Menteri Lingkungan Hidup. Dalam Kabinet Reformasi Pembangunan ( 1998 - 1999 ) telah diangkat dr. Panangian Siregar sebagai Menteri Negara Lingkungan Hidup. Dalam Kabinet Persatuan ( 1999 - 2001) sebagai Menteri Alexander Sony Keraf. Dalam Kabinet Gotong Royong (2001 - 2004 ) sebagai Menteri 
Nabiel Makarim. Dalam Kabinet Indonesia Bersatu I sebagai Menteri Lingkungan Hidup Rachmad Witular dan pada Kabinet Indonesia Bersatu II diangkat sebagai Menteri Lingkungan Hidup Gusti Muhammad Hatta. Sehingga dapat dihitung menteri lingkungan hidup mulai pertama sampai sekarang telah dijabat oleh 8 orang yang menjabat sebagai Menteri Lingkungan Hidup.

Dengan tugas terutama mempersiapkan perumusan kebijakan Pemerintah mengenai segala sesuatu yang bersangkutan dengan tugas pelaksanaan pengawasan pembangunan dan pengelolaan lingkungan hidup serta mengkoordinasi dan menangani segala kegiatan pengelolaan, pengembangan dan perlindungan lingkungan hidup.

Pada 1978 Kantor Menteri Negara Pengawasan Pembangunan dan Lingkungan Hidup mulai berinisiatif untuk membuat rangcangan undang-undang tentang pengelolaan lingkungan hidup. Dibentuklah Tim Kerja yang khusus mempersiapkan konsep peraturan perundang lingkungan hidup. Atas persetujuan Dewan Perwakilan Rakyat maka pada tanggal 11 Maret 1982, lahirlah Undang-Undang Nomor 4 Tahun 1982 (UULH Th. 1982) tentang Ketentuan-ketentuan Pokok Lingkungan Hidup. Dengan demikian terbukalah lembaran baru bagi kebijaksanaan lingkungan hidup di Indonesia menuju pembangunan hukum lingkungan berdasarkan prinsip-prinsip hukum lingkungan modern yang diakui secara international.

Situasi politik hukum yang tengah berlangsung secara global sangat mempengaruhi terbentuknya UULH Nomor 4 Tahun 1982, karena saat itu Pemerintah Indonesia sedang giat-giatnya menawarkan investasi penanaman modal bagi investor asing, sementara konsep lingkungan dalam konsep lingkungan global sedang dibahas. Oleh karena itu Indonesia menawarkan konsep pembangunan yang berwawasan lingkungan yaitu kesejajaran antara pembangunan dan pengelolaan lingkungan. Pembangunan boleh dapat terus berlangsung dengan segala dinamika dan masalahnya, akan tetapi pembanguan tersebut tidak boleh menyebabkan rusaknya daya dukung lingkungan demi generasi masa depan. Kita tidak perlu mempertentangkan antara lingkungan dan pembangunan. Dalam TAP MPR : NO II/MPR/1993 tentan GBHN yan antara lain menentukan pemanfaatan sumber daya alam bagi peningkatan kesejahteraan rakyat, telah diupayakan secara menyeluruh dan terpadu dengan memperhatikan keseimbangan dan keserasian fungsi lingkungan hidup serta senantiasa memperhatikan prinsip-prinsip pembangunan yang berkelanjutan demi untuk kepentingan generasi yang akan datang. Ini 
merupakan komitmen politik dari pihak penguasa tentang bagaimana kita menyikapi permasalahan lingkungan. Hal ini menimbulkan implikasi bahwa semua kegiatan pembangunan harus memberikan jaminan bahwa pembangunan tersebut tidak akan merusak lingkungan dan dengan demikian pembanguan yang dilaksanakan harus berwawasan lingkungan

Dalam kedudukannya, UULH Nomor 4 Tahun 1982 memberikan uraian mengenai kebijaksanaan lingkungan hidup di Indonesia dalam hubungannya dengan tujuan dari pada pengelolaan lingkungan hidup yang tercermin di dalam Pasal 4, yang menyatakan “ Pengelolaan lingkungan hidup bertujuan : a. tercapainya keselarasan hubungan antara manusia dengan lingkungan hidup sebagai tujuan membangun manusia Indonesia seutuhnya; b. terkendalinya pemanfaatan sumber daya secara bijaksana; c. terwujudnya manusia Indonesia sebagai pembina lingkungan hidup; d. terlaksnanya pembangunan berwawasan lingkungan untuk kepentingan generasi sekarang dan mendatang; e. terlindunginya negara terhadap dampak kegiatan diluar wilayah negara yang menyebabkan kerusakan dan pencemaran lingkungan. ${ }^{10}$

Di samping itu UULH ini juga juga bisa dipergunakan untuk menilai dan menyesuaikan semua peraturan yan memuat segi-segi lingkungan hidup yang sudah berlaku, dengan demikian diharapkan bahwa semua peraturan tersebut dapat dalam satu sistem hukum lingkngan di Indonesia.

Secara konsep pikiran dasar dari UULH Nomor 4 Tahun 1982 itu dapat diuraikan sebagai berikut : a. bahwa lingkungan hidup sebagai konsep kewilayahan. b. wawasan tentang hubungan manusia dengan lingkungan hidup. Kedua hal ini menimbulkan implikasi dan konsekuensi yang dijabarkan dalam azas-azas yang dianut yaitu : a. Hak atas lingkungan hidup yang baik dan sehat. b. Pelestarian kemampuan lingkungan hidup. c. Penguasaan sumber daya alam oleh negara. d. Keterpaduan dalam penyelenggaraan pengelolaan lingkungan hidup.

Terlepas dari berbagai masalah yang timbul dan dialaminya, UULH Nomor 4 Tahun 1982 yang telah menandai awal pengembangan perangkat hukum sebagai dasar bagi upaya pengelolaan lingkungan hidup, dalam kurun waktu sejak diundangkanya telah terjadi peningkatan kesadaran lingkungan hidup di masyarakat, tumbuhnya peran serta masyarakat, makin banyaknya ragam organisasi

${ }^{10}$ Ibid., hlm. 91 
lingkungan dan peningkatan kepeloporan masyarakat dalam pelestarian sehingga masyarakat tidak hanya sekedar berperan tetapi juga mampu berperan secara nyata.

Sementara itu permasalahan hukum yang berkembang memerlukan pengaturan dalam bentuk hukum demi menjamin kepastian hukum. Di sisi lain perkembangan lingkungan global serta aspirasi internasional makin mempengaruhi usaha pengelolaan lingkungan sehingga pemerintah memandang perlu untuk memperbaharui dan menyempurnakan UULH Nomor 4 Tahun 1982.

Dengan dasar pemikiran tersebut Pemerintah bersama Dewan Perwakilan Rakyat telah mengganti Undang-Undang Lingkungan Hidup Nomor 4 Tahun 1982 dengan Undang-Undang Nomor 23 Tahun 1997 tentang Pengelolaan Lingkungan Hidup dan disempurnakan dengan Undang-Undang Nomor 32 Tahun 2009 tentang Perlindungan dan Pengelolaan Lingkungan Hidup. Undang-undang ini bertujuan antara lain melindungi wilayah Negara Keastuan Republik Indonesia dari pencemaran dan kerusakan lingkungan hidup, menjamin keselamatan, kesehatan, dan kehidupan manusia, makhluk hidup dan kelestarian ekosistem serta menjamin terpenuhinya keadilan generasi masa kini generasi masa depan dan mengendalikan pemanfaatan sumberdaya alam dengan mewujudkan pembangunan berkelanjutan dan mengantisipasi isu lingkungan global.

Pertumbuhan masyarakat telah pula membawa tantangan dalam upaya peningkatan kesejahteraan lahiriyah dan batiniah beserta matra pemerataannya berkeadilan sosial. ${ }^{11}$ Pembangunan dalam dirinya mengandung perubahan besar yang meliputi struktur ekonomi, fisik wilayah, perubahan sumber daya alam dan lingkungan hidup, perubahan tehnologi, dan perubahan system nilai.

\section{Wewenang untuk Melakukan Pengawasan}

Dalam Bab XII Undang-Undang Nomor 32 Tahun 2009 bagian kesatu mengatur tentang pengawasan dalam perlindungan dan pengelolaan lingkungan hidup mulai Pasal 71 sampai Pasal 75. Pasal 71 ayat (1) Menteri, gubernur, atau bupati/walikota sesuai dengan kewenangannya wajib melakukan pengawasan terhadap ketaatan penanggung jawab usaha dan/atau kegiatan atas ketentuan yang ditetapkan dalam peraturan perundang-undangan di bidang perlindungan dan pengelolaan lingkungan hidup.

${ }^{11}$ Emil Salim, Pembangunan Berwawasan Lingkungan, Penerbit LP3ES, Jakarta,1986, hlm. 43 
Ayat (2) Menteri, gubernur, atau bupati/walikota dapat mendelegasikan kewenangannya dalam melakukan pengawasan kepada pejabat/instansi teknis yang bertanggung jawab di bidang perlindungan dan pengelolaan lingkungan hidup.

Ayat (3) Dalam melaksanakan pengawasan, Menteri, gubernur, bupati/walikota menetapkan pejabat pengawas lingkungan hidup yang merupakan pejabat fungsional.

Instansi yang berwenang dalam melakukan pelaksanaan pengendalian lingkungan hidup, termasuk dampak lingkungan hidup adalah Kantor Lingkungan Hidup/Bapedal di tinglat Propinsi dan Kantor Lingkungan Hidup/Bapedalda di tingkat Kabupaten/Kotamadya. Kantor lingkungan hidup/Bapedal maupun Bapedalda termasuk lembaga teknis daerah yang dipimpin oleh seorang Kepala dan bertanggung jawab langsung kepada Gubernur atau Bupati/Walikota. Pembiayaan kegiatan operasionalnya adalah dimasukan kedalam APBD Propinsi atau Kabupaten/Kota masing masing, karena kedua instansi ini termasuk perangkat kerja daerah.

\section{Kewenangan pengendalian pencemaran air akibat limbah industri perusahaan}

Pada dasarnya kewenangan pengendalian pencemaran air di daerah baik yang berasal dari limbah industri maupun dari sumber lain, berada pada Gubernur sebagai Kepala Daerah Tingkat I. Hal ini diatur baik dalam pasal 13 Peraturan Pemerintah Nomor 20 Tahun 1990 tentang pengendalian pencemaran air maupun di dalam Pasal 18 ayat (2) Peraturan Pemerintah Nomor 41 Tahun 1999 tentang Pengendalian Pencemaran Udara. Akan tetapi dalam pengendalian pencemaran udara, kewenangan Gubernur adalah melakukan koordinasi, terutama dalam hal pencemaran lintas Kabupaten/Kota. Pencemaran yang terjadi pada suatu daerah kabupaten/kota yang berwenang melaksanakan pengendaliannya dalah Bupati/ Walikota daerah yang bersangkutan.

Tindakan-tindakan yang dilakukan Gubernur adalah : 1. menunjuk instansi teknis yang bertanggung jawab di bidang pengelolaan lingkungan hidup didaerah (Pasal 4 ayat (1) PP Nomor 20 Tahun 1990). Untuk melakukan inventarisasi kualitas dan kuantitas air, data ini digunakan untuk menentukan peruntukan air dan baku mutu air, dasar perhitungan daya tampung beban pencemaran air dan dasar penilaian tingkat pencemaran air; 2. mengidentifikasikan sumber-sumber pencemaran air (Pasal 5 ayat (1) PP Nomo 20 Tahun 1990); 3. menetapkan baku mutu limbah cair yang lebih ketat dari yang ditentukan oleh Menteri Lingkungan 
Hidup setelah berkonsultasi dengan menteri lingkungan hidup; 4. memberikan izin pembuangan limbah cair ke dalam air (seperi sungai, danau) yang biasanya dicantumkan dalam izin HO (Pasal 25 jo, 26 ayat (1 dan 2) PP 20 Tahun 1990). Apabila pelaku kegiatan ingin membuang limbah cair ke tanah permohonan izin harus dimintakan kepada Menteri Lingkungan Hidup; 5. melakukan pengawasan kualitas air dengan menunjuk instansi di daerah yang meliputi tugas pemantauan dan evaluasi baku mutu limbah cair, pemantauan dan perubahan kualitas air, pengumpulan dan evaluasi data yan berhubungan dengan pencemaran airserta evaluasi laporan dari penanggung jawab kegiatan tentang pembuanan limbah cair dan analisisnya (Pasal 30 PP Nomor 20 Tahun 1990).

\section{Kewenangan Gubernur dalam hal pengendalian pencemaran udara}

Adapun kewenangan Gubernur dalam hal pengendalian pendemaran udara meliputi: 1. dapat menentukan baku mutu udara ambien daerah berdasarkan baku mutu ambien nasional, bahkan Gubernur dapat menentukan baku mutu yang lebih ketat (Pasal 5 ayat (2) PP No. 41 Tahun 1999); 2. berdasarkan keputusan Menteri Negara Lingkungan Hidup No KEP. -13/MENLH/ 3/1995, Gubernur diberi kewenangan untuk menetapkan baku mutu emisi yang lebih ketat dari ketentuan yang ditetapkan oleh Menteri Negara Lingkungan Hidup, namun penetapan ini harus mengikutsertakan pihak-pihak yang berkepentingan (dalah hal ini bisa berarti stake holders, pelaku usaha maupun masyarakat); 3. Gubernur dapat menentukan baku tingkat kebisingan yang lebih ketat dari yang diatur oleh Menteri Negara Lingkungan Hidup. Dalam Keputusan Menteri Lingkungan Hidup, tingkat kebisingan bagi insdustri yang diperbolehkan adalah $70 \mathrm{~dB} ; 4$. Gubernur/Bupati/Walikota berwenang untuk melakukan pengawasan terhadap pelaku kegiatan usaha/kegiatan industri yang dibantu oleh BPLHD.

\section{Kewenangan Pemerintah Daerah menurut Undang-undang Nomor 32 Tahun 2004}

Daerah yang dimaksud dalam Undang-Undang Nomor 32 Tahun 2004 adalah daerah otonom yaitu " kesatuan masyarakat hukum yang mempunyai batas daerah tertentu berwenang mengatur dan mengurus kepentingan masyarakat setempat menurut prakarsa sendiri berdasarkan aspirasi masyarakat dalan ikatan Negara Kesatuan Republik Indonesia. Selanjutnya dalam Pasal 2 disebutkan bahwa wilayah yang bersifat otonom adalah daerah Propinsi (juga berkedudukan sebagai wilayah administrasi yan menjadi wilayah kerja Gubernur selaku wakil pemerintah pusat), daerah Kabupaten dan daerah Kota (Pasal 4 ayat (1) UU No. 22 Tahun 1999). 
Berdasarkan Pasal 9 ayat (1) dijelaskan bahwa “Kewenangan Propinsi sebagai daerah otonom mencakup kewenangan dalam bidang pemerintahan yag bersifat lintas kabupaten dan kota, serta kewenangan dalam bidang pemerintahan daerah tertentu lainnya. “ Dalam penjelasan pasal ini disebutkan kewenangan dalam bidang tertentu salah satunya adalah pengendalian lingkungan hidup, kewenangannya masih terletak pada Daerah Propinsi.

Berkaitan dengan penggunaan sumber daya alam (yang banyak digunakan dalam berbagai kegiatan industri) yang tersedia di wilayahnya, daerahlah (bisa Propinsi, Kabupaten, Kota) yang berwenang mengelola sumber daya alam tersebut dan sekaligus bertanggung jawab memelihara kelestarian lingkungan hidup sesuai dengan peraturan perundangan yang berlaku. Artinya untuk kegiatan pelestarian yang berhubungan dengan pemanfaatan sumber daya alam, kewenangan juga berada di daerah Kabupaten/Kota.

\section{Penegakan Hukum}

Dalam Kabinet Indonesia Bersatu jilid II yang dinahkodai oleh Susilo Bambang Yodoyono dan Budiono ini upaya untuk melakukan penegakan hokum lingkungan dan penanganan berbagai kasus lingkungan belum menunjukkan hasil menggembirakan. Pemerintah oleh kalangan aktivis lingkungan dinilai hanya mengurusi masalah politik dan sibuk mengurusi partai tanpa ada keberpihakan pada lingkungan. Akibatnya persoalan lingkungan, seperti kasus pencemaran Buyat, illegal loging, kebakaran hutan pencemaran dan perusakan lingkungan disejumlah daerah tidak dapat ditangani secara tuntas. Kebijakan pemerintah yang tidak memihak pada lingkungan berakibat pada terjadinya musibah yang terus terjadi secara beruntun di berbagai tempat hampir di seluruh wilayah Indonesia. Gambaran tersebut menunjukan adanya indikasi bahwa bekerjanya lembaga pengadilan dan penegakan hukum lingkungan di Indonesia masih amat dipengaruhi kepentingan politik. ${ }^{12}$

Undang-undang Nomor 32 Tahun 2009 tentang Perlindungan dan Pengelolaan Lingkungan Hidup (UUPPLH) mengatur permasalahan lingkungan sebagai dasar pedoman bagi aparat penegak hukum untuk menjerat pelaku tindak pidana lingkungan dikenakan hukuman pidana sesuai aturan yang berlaku. Pasal 1 angka

${ }^{12}$ Absori, Penegakan Hukum Lingkungan Pada Era Reformasi, artikel dalam Jurnal Imu Hukum, Vol. 8. No. 2 , September 2005, hlm. 10 
16, menyatakan definisi perusakan lingkungan hidup adalah “ Tindakan orang yang menimbulkan perubahan langsung atau tidak langsung terhadap sifat fisik, kimia, dan atau hayati lingkungan hidup sehingga melampaui ktriteria baku kerusakan lingkungan hidup".

Pasal 1 angka 17 juga menyatakan bahwa kerusakan lingkungan hidup adalah perubahan langsung dan/atau tidak langsung terhadap sifat fisik, kimia, dan/atau hayati lingkungan hidup yang melampaui kriteria baku kerusakan lingkungan hidup. Dengan demikian di dalam undang-undang ini, perbuatan yang menimbulkan pencemaran lingkungan dan atau perusakan lingkungan hidup yang dilakukan dengan sengaja atau tidak sengaja atau kealpaan diarahkan menjadi perbuatan tindak pidana yang dalam undang-undang ini merupakan kejahatan (Pasal 97 UUPPLH).

Sesuai Pasal 71 ayat (1) Menteri, gubernur, atau bupati/walikota sesuai dengan kewenangannya wajib melakukan pengawasan terhadap ketaatan penanggung jawab usaha dan/atau kegiatan atas ketentuan yang ditetapkan dalam peraturan perundangundangan di bidang perlindungan dan pengelolaan lingkungan hidup. Ayat (2) Menteri, gubernur, atau bupati/walikota dapat mendelegasikan kewenangannya dalam melakukan pengawasan kepada pejabat/instansi teknis yang bertanggung jawab di bidang perlindungan dan pengelolaan lingkungan hidup. Ayat (3) Dalam melaksanakan pengawasan, Menteri, gubernur, bupati/walikota menetapkan pejabat pengawas lingkungan hidup yang merupakan pejabat fungsional.

Di dalam Pasal 76 UUPPLH ini mengatur tentang sanksi administrasi. Menteri, gubernur, atau bupati/walikota menerapkan sanksi administratif kepada penanggung jawab usaha dan/atau kegiatan jika dalam pengawasan ditemukan pelanggaran terhadap izin lingkungan. Sanksi administratif terdiri atas; teguran tertulis, paksaan pemerintah, pembekuan izin lingkungan atau pencabutan izin lingkungan.

Pasal 80 ayat (1) mengatur tentang paksaan pemerintah kepada penanggung jawab usaha dan/atau kegiatan yang yang melanggar izin lingkungan berupa : a. penghentian sementara kegiatan produksi, b. pemindahan sarana produksi, c. penutupan saluran pembuangan air limbah atau emisi, d. pembongkaran, e. penyitaan terhadap barang atau alat yang berpotensi menimbulkan pelanggaran, $f$. penghentian sementara seluruh kegiatan, g. tindakan lain yang bertujuan untuk menghentikan pelanggaran dan tindakan pemulihan fungsi lingkungan hidup. 
Pengenaan paksaan pemerintah dapat dijatuhkan tanpa didahului teguran apabila pelanggaran yang dilakukan menimbulkan : a. ancaman yang sangat serius bagi manusia dan lingkungan hidup, b. dampak yang lebih besar dan lebih luas jika tidak segera dihentikan pencemaran dan/atau perusakannya, c. kerugian yang lebih besar bagi lingkungan hidup jika tidak segera dihentikan pencemaran atau kerusakannya ayat (2).

Pasal 87 Undang-Undang No. 32 Tahun 2009 mengatur tentang kewajiban penanggung jawab usaha untuk memberi ganti rugi kepada orang atau lingkungan yang dirugikan. Selain korban maka organisasi lingkungan hidup juga dapat meminta pertanggungjawaban perdata kepada pelaku kegiatan usaha (Pasal 92). Akan tetapi apabila gugatan tersebut dilakukan oleh organisasi lingkungan hidup, permintaan yang dapat diajukan hanya sebatas melakukan tindakan tertentu, kecuali biaya atau pengeluaran nyata. Sehingga bagi masyarakat yang menderita kerugian akibat pencemaran dan atau perusakan lingkungan hidup dapat melakukan-gugatan secara bersama-sama dengan cara gugatan perwakilan kelompok (Pasal 91). Hal terpenting dalam melakukan gugatan ini, kelompok masyarakat dapat menempuh cara-cara diluar pengadilan yang dikenal dengan mekanisme alternatif pnyelesaian sengketa.

Bab XIV mengatur tentang Penyidikan dan Pembuktian. Selain penyidik pejabat polisi, pejabat pegawai negeri sipil tertentu di lingkungan instansi pemerintah yang lingkup tugas dan tanggung jawabnya di bidang perlingungan dan pengelolaan lingkungan lingkungan hidup diberi wewenang sebagai penyidik sebagai dimaksud dalam hukum acara pidana untuk melakukan penyidikan tindak pidana lingkungan hidup.

Penyidik Pegawai Negeri Sipil berwenang antara lain : 1) melakukan pemeriksaan atas kebenaran laporana atau keterangan berkenaan dengan tindak pidana di bidang perlindungan dan pengelolaan lingkungan hidup. 2) melakukan pemeriksaan terhadap setiap orang yang diduga melakukan tindak pidana di bidang perlindungan dan pengelolaan lingkungan hidup. 3) meminta keterangan dan bahan bukti dari setiap orang berkenaan dengan peristiwa tindak pidana di bidang lingkungan hidup. 4)melakukan pemeriksaan atas pembukuan, catatan, dan dokumen lain merkenaan dengan tindak pidana di bidang lingkungan hidup. 5) melakukan penyitaan terhadap bahan dan barang hasil pelanggaran yang dapat dijadikan bukti dalam perkara tindak pidana lingkungan hidup. 6) meminta bantuan 
ahli dalam rangka tugas penyidikan. 7) menghentikan penyidikan. 8) melakukan penggeledahan terhadap badan, pakaian, ruangan atau tempat lain yang diduga merupakan tempat dilakukannya tindak pidana atau menangkap dan menahan pelaku tindak pidana.

Adapun untuk pembuktian diatur dalam Pasal 96, alat bukti yang sah dalam tuntutan tindak pidana lingkungan terdiri atas; keterangan saksi, keterangan ahli, surat, petunjuk, keterangan terdakwa, alat bukti lain, termasuk alat bukti yang diatur dalam peraturan perundang-undangan.

Sistem pembuktian yang harus dilakukan penggugat atau aparat penegak hukum merupakan problem pembuktian yang sulit dan pelik selama ini. Karena aparat penegak hukum akan mengalami kesulitan terutama dalam masalah pembuktiannya yang berkaitan dengan hal-hal yang bersifat sangat tehnis untuk menentukan klasifikasi ataupun unsur-unsur yang harus dipenuhi sehingga dikatakan sebagai pelaku tindak pidana lingkungan. Kemudian juga adanya keterbatasan pengetahuan tentang permasalahan, sarana, prasarana, dana maupun pemahaman terhadap substansi hukum karena rata-rata korban adalah orang-orang yang berpendidikan rendah dan kondisi ekonominya lemah.

Setelah melihat uraian tentang pembaharuan dan perbedaan substansial terhadap Undang-Undang Nomor 32 Tahun 2009, apakah undang-undang tersebut berlaku efektif dalam menanggulangi permasalahan lingkungan terutama masih sering terjadinya pencemaran air oleh limbah industri atau ada segelintir manusia yang secara sadar masih membuang sampah ke dalam sungai, sehingga sungai tersebut menjadi kotor.

Efektivitas hukum dapat dijelaskan sebagai suatu keadaan dimana terjadi kesesuaian antara cita-cita yang terkandung di dalam substansi hukum dengan realitas berlakunya hukum tersebut di dalam masyarakat. Hukum dianggap kurang atau tidak efektif apabila terdapat disparitas antara realita hukum dan ideal hukum, sehingga hukum tersebut harus dirombak dan disusun kembali. Kalau ideal hukum itu mengacu kepada tujuan atau cita-cita yang terkandung di dalam isi/substansi hukum, realita hukum mengacu kepada pengertian penerapan hukum yang indikatornya adalah kesadaran dan atau kepatuhan hukum yang tercermin dalam perilaku warga masyarakat tersebut. Maka dapat dikatakan bahwa efektivitas hukum yang berlaku dalam suatu masyarakat tidak terlepas dari konsep kesadaran hukum dan atau kepatuhan hukum dari masyarakat itu sendiri. 
Masih sering terjadinya pencemaran yang dilakukan oleh pihak perusahaan atau industri dan masih rendahnya ketaatan dan kepatuhan serta kesadaran warga masyarakat untuk menjaga lingkungan yag bersih dan sehat menjadi indikator bahwa penegakan hukum terhadap pengelolaan lingkungan yang bersih dan sehat belum berjalan. Dengan demikian secara implementasi efektivitas Undang-undang Nomor 32 Tahun 2009 masih rendah hal ini dikarenakan penegakan hukum terutama dalam masalah pembuktian sulit dilakukan dan pengawasan dalam rangka pengendalian dan pengelolaan lingkungan hidup dapat dikatakan masih jalan ditempat walaupun dari aspek politik hukum secara substansial isi / materi hukum lingkungan tersebut telah banyak terjadi perubahan disesuaikan dengan kondisi sosial masyarakat.

\section{Penutup}

Dari uraian di atas maka dapat disimpulkan sebagai berikut, pembaharuan undang-undang pengelolaan Lingkungan Hidup dipengaruhi oleh berbagai perkembangan perubahan yang terjadi di dalam masyarakat seperti misalnya pengaruh era demokratisasi, industrialisasi, kemajuan ilmu pengetahuan dan tehnologi dan semakin maraknya tuntutan kesejahteraan dari berbagai fihak. Aspek politik yang dikandung dalam politik hukum Undang-Undang Nomor 32 tahun 2009 tentang perlindungan dan pengelolaan lingkungan hidup belum berjalan sesuai dengan tujuan politik hukumnya, karena sumber daya alam yang ada belum dapat dipergunakan untuk sebesar-besarnya kemakmuran dan kesejahteraan rakyat. Selain itu juga masih banyak terjadi pencemaran air, polusi udara, pembalakan hutan dan perbuatan lain para pihak-pihak yang merusak lingkungan. Maka perlu melaksanakan pengelolaan lingkungan hidup untuk melestarikan dan mengembangkan kemampuan lingkungan hidup yang serasi, selaras dan seimbang guna menunjang terlaksananya pembangunan yang berkelanjutan yang berwawasan lingkungan hidup.

Penegak hukum dalam memahami sistem hukum lingkungan dirasakan masih mengalami kesulitan. Kurangnya pemahaman para aparat penegak hukum akan menimbulkan tatanan yang terbentuk dalam satu kesatuan sistem hukum nasional akan menyimpang dari pada arah tujuan politik hukum. Penegakan hukum sulit dilakukan oleh karena sulitnya pembuktian dan menentukan kriteria baku tentang kerusakan lingkungan. 
Politik hukum undang-undang perlindungan pengelolaan lingkungan hidup yang dilakukan oleh pemerintah harus memberikan jaminan bahwa dengan produk hukum tersebut maka lingkungan hidup akan lestari menuju kesejahteraan hidup warga masyarakat. Maka produk hukum yang diharapkan adalah produk hukum yang berkarakter responsif, proses pembuatannya bersifar partisipatif, yakni mengundang sebanyak-banyaknya partisipasi masyarakat melalui kelompokkelompok sosial dan individu-individu di dalam masyarakat.

Perlu dedikasi dan profesionalisme aparat hukum dalam menangani dan memberikan sanksi tegas kepada perusahaan maupun perorangan yang sengaja maupun tidak sengaja merusak lingkungan demi penegakan hukum lingkungan yang selama ini masih lemah.

\section{Daftar Pustaka}

Alkostar, Artidjo, M. Sholeh Amin, Pembangunan Hukum Dalam perspektifPolitik Hukum Nasional, Lembaga Bantuan Hukum, Yogyakarta, 2001.

Absori, Penegakan Hukum Lingkungan pada Era Perdagangan Bebas, Universitas Muhammadiyah Press, Surakarta, 2006.

Askin, Mohammad, Hukum Lingkungan, Yayasan peduli Energi Indonesia (YPEI), Jakarta, 2008.

C.F.G. Hartono, Sunaryati, Politik hukum Menuju Satu Sistem Hukum Nasional, Alumni, Bandung, 1991.

Hardjasoemantri, Koesnadi, Hukum Tata Lingkungan, Cetakan ke-16 Edisi ke-7, Gajah Mada University Press, Yogyakarta, 2001.

Kementerian Ling. Hidup, Program Bangun Praja, Yayasan peduli Energi Indonesia (YPEI), Jakarta, 2003.

Mahfud MD, Moh., Pergulatan Politik dan Hukum di Indonesia, Gama Media, Yogyakarta, 1999.

Rangkuti, Siti Sundari, Hukum Lingkungan dan Kebijaksanaan Lingkungan, Airlangga University Press, Malang, 2005.

R. Tjiptosudibyo, Soebekti, Kitab Undang-Undang Hukum Perdata, Pradnya Paramita, Jakarta, 1983.

Silalahi, Daud, Hukum Lingkungan dalam Sistem Penegakan Hukum Lingkungan Indonesia, Cetakan ke-1, Alumni, Bandung, 1992.

Salim, Emil, Lingkungan Hidup dan Pembangunan, Cetakan ke-5, Mutiara Sumber Widya, Jakarta, 1995. 
Salim, Emil, Pembangunan Berwawasan Lingkungan, LP3ES, Jakarta, 1986.

Undang-Undang no. 32 tahun 2009, tentang Perlindungan dan Pengelolaan Lingkungan Hidup (UUPPLH). 